NASA Technical Memorandum 102547

\title{
Advanced Launch System (ALS): Electrical Actuation and Power Systems Improve Operability and Cost Picture
}

Gale R. Sundberg

Lewis Research Center

Cleveland, Ohio

(NASA-TA-102547) ATVANCED LAUNCH SYSTEM

N90-21271

(ALO): ELCCTRICAL ACTUATION AND POWER

SYSTEMS IMPRCVE OPERARILITY ANO COST PICTURF

(NASA) $5 \mathrm{P}$ CSCL O9C

CSCL O9C G\$33

Unclas

0271306

Prepared for the

National Aerospace and Electronics Conference (NAECON) sponsored by the Institute of Electrical and Electronics Engineers Dayton, Ohio, May 21-25, 1990

\section{N/Sก}




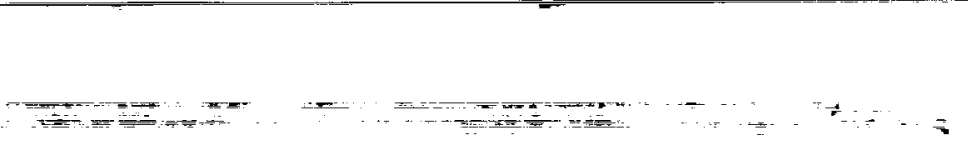

-...........

$=$ 
ADVANCEO LAUNCH SYSTEM (ALS): ELECTRICAL ACTUATION AND POWER SYSTEMS

IMPROVE OPERABILITY AND COST PICTURE

Gale R. Sundberg

National Aeronautics and Space Adminlstration

Lewis Research Center

Cleveland, Ohio 44135

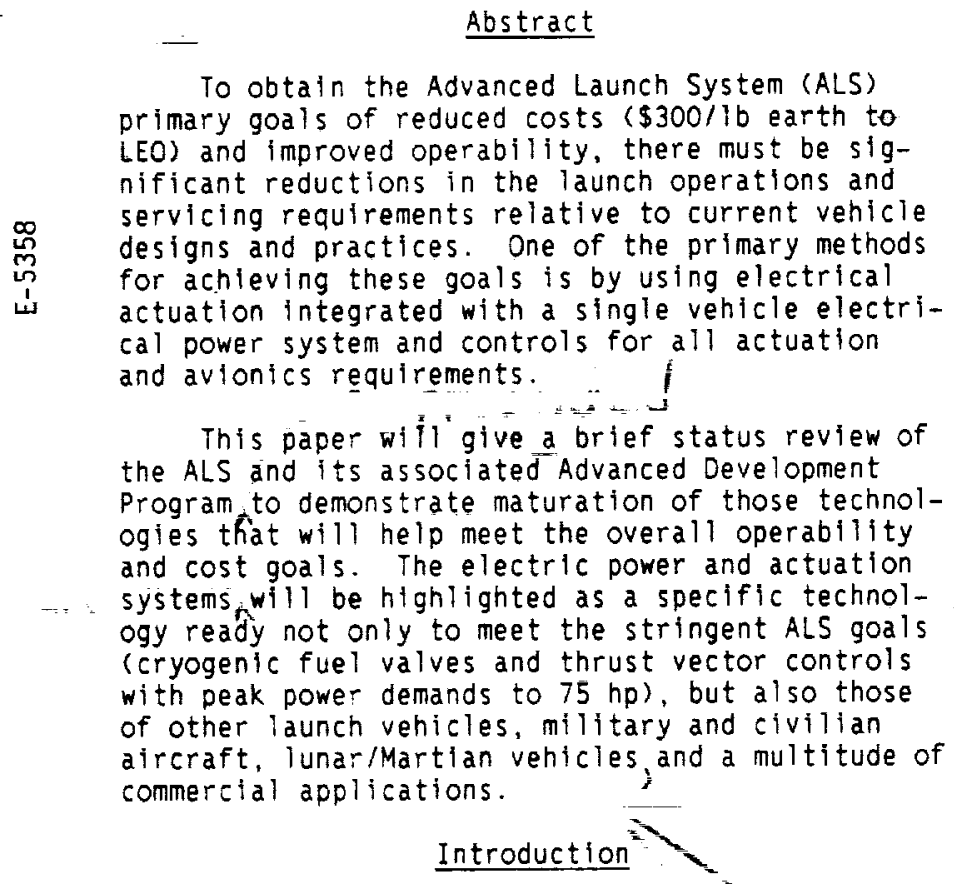

To obtain the Advanced Launch System (ALS) primary goals of reduced costs ( $\$ 300 / 1 \mathrm{~b}$ earth to LEO) and improved operability, there must be signiflcant reductions in the launch operations and servicing requirements relative to current vehicle designs and practices. One of the primary methods for achieving these goa is is by using electrical actuation integrated with a single vehicle electrica) power system and controls for all actuation and avionics requirements.

Electrical actuation will ellminate a major and persistent problem with liquid englne valves, hydraulics and plumbing causing propulsion fallures and delays such that launch reliability has plateaued in the 0.92 to 0.96 range. It will also significantly reduce the energy, peak power requirements and weight, while raising system efficiencies from 2 vercent to well over 80 percent when compared to centralized hydraulics.

The greatest benefits, however, accrue due to savings in prelaunch testing time permitted by the elimination of hydraulies and plumbing, and the substitution of electrical actuation and an integrated electrical power system. The magnitude of these savings could exseed 10 percent of the total vehicle operations sosts according to a study by the General Jynamic: Corporation showing a 5400 manhour savings for their Atlas/Centaur (A/C) launch venicie and a 16000 manhour savings for the Space Shuttic sased on a Boeing Aerospace study of operations $\equiv:$ Cape Kennedy. Figure 1 illustrates these Do:ential cost savings for electrical actuation systems.
In the case of the Space Shuttle a preliminary Assured Shuttle Availabllity study has shown a reduced turn-around time at KSC using electric actuators, such that at least one additional Shuttle flight per year may be possible. In addition, a weight savings of $2300 \mathrm{~kg}$ could either increase the payload or engine margins.

Recent advances in power control and distribution systems and newly demonstrated capabllities for high torque/speed control of a larger class of inherently rugged, induction motors using pulsepopulation-modulation with field-oriented control from a high frequency resonant link make the all electric approach even more attractive. For example, selective steering of high frequency. small energy pulses and switching at zero crossing significantly reduces the slze and welght of the electronics while practically ellminating EMI/EMC effects. In addition, using embedded microprocessors and smart components with microchip BITE for remote identification/self-checking will enable distributed system intelligence and fault tolerance in both of the power and the avionics systems without massive sof tware investments.

This paper will give a brief status review of the ALS program and its associated Advanced Development Program to demonstrate maturation of those technologies that will help meet the overall operability and cost goals. Figure 2 shows the primary subsystems that make up a typical electromechanical actuator for thrust vector control of a launch vehicle. The electric power and actuation systems will be highlighted as a specific technology ready not only to meet the stringent ALS goals cryogenic fuel valves and thrust vector controls with peak power demands to $75 \mathrm{hp}$ ), but al so those of other launch vehlcles, particularly evolutionary Space Shuttle, Assured Crew Return Vehicle, milltary and civilian aircraft, lunar/Martian vehicles and a multitude of commercial applications.

\section{Major Objectives}

The scope of the ALS Advanced Development Program tasks is to develop, demonstrate and transfer (to vehicle/equipment manufacturers) the technology for electromechanical actuators (EMA) and/or contained electro-hydraulic actuators (EHA) integrated with a single vehicle electrical power system and controls. Both EMAs and EHAs are electrically driven by motors and will be referred to as electric actuators.

Reduce KSC Turn-Around Costs and Standdown Time: Increase Launch Rate: Decrease Welght

For any launch system the key objective is to reduce the turn-around time and costs at KSC and. thereby, Increase the launch rate, improve the dispatch reliability and enable launchs even from a. last second hold. Use of electric actuators will 
e) iminate excessive manpower intensive testing and qualiftcation procedures. Eliminating centralized hydraulics will eliminate ground support carts and associated equipment and the problems of fluid contamination and hydraulic silting. At the present time a study team at KSC composed of Flight Controls personnel and Lockheed are revtewing NSTS logbooks to assess turn-around flow and subsystem processing costs due to the hydraulic systems.

They are establishing an analysis network of critical paths to provide quantitative trades of several items that impact Shuttle operations and the number of launches per year.

Improve Redundance, Reliability, Dlspatch Rellability and Safety

Electric actuation is a demand driven system provlding high peak power and torque, but it uses small amounts of total energy. Therefore, APUs and their associated hazardous fuels may be eliminated and replaced by batteries, fuel cells or an electric APU. In addition electric actuators require low amounts of standby power and energy. Electric motor driven actuators are easy to implement and to integrate automated, remote, self check-out through microchip bullt-in-test (BITE). Smart BITE microchips designed in, bulit-in at manufacture and easliy monitored by technicians and controllers provide a path to vehicle health monitoring with a minimum of software.

\section{Significant Research Activities}

There are six candidate Government supported programs that are working on relevant technologles or could have significant applications for electric actuators and an integrated power distribution and control system. The programs are listed below with a brief explanation and noteworthy technology.

\section{Advanced Launch System}

Four Advanced Development Tasks are directed to the development and demonstration of electrical actuators and electrical power systems for the proposed new family of heavy lift launch vehicles. Actuators for thrust vector control (TVC), fuel valves and others with ratings in the ranges of 5 , 25, 40, and $75 \mathrm{hp}$ are being developed and subsystem demonstrations before March 1992. Figure 3 shows the ALS EMA system demonstration activities and milestones. Inspection of Table I shows that these actuator values $\mathrm{fit}$ easlly within the actuation reauirements for all launch vehicles commonly used by the United States today including the Space Siuttle.

The primary development work on three of the tasks is being done by two of the ALS vehicle prime contractors - General Dynamics Space Systems and Boeing Aerospace Company - and one of the engine contractors - Aerojet General. The fourth task is being conducted by Lewis to provide advanced motor orive iecnnology. motor designs, BITE concepts and vehicielactudior requirements and transfer the tecnnologies directly to all the primes. The $5 \mathrm{hp}$ drive has veer cemonstrated, the 25 hp drive and actuator will be tested in Marcn 1990, and the 30 and 40 no actuators will be ready by eariy 1991 .

The powe semiconductors necessary to meet the peak horsepower ratings are now avallable and improved MOSFET Controlled Thyristors (MCT) will be avallable in 6 months. Circuit topologies and system architectures are available, which meet required redundancy, fault tolerance and fault containment.
An appropriate power control and distribution system integrated with an avionic and propulsion system will demonstrated in 1992 .

\section{Space Shuttle Evolution/Shuttle "C"}

JSC has supported several electric actuation and power source studies over several years. A preliminary Assured Shuttle Avallability study by Rockwell Downey concluded that electric actuation was feasible, the technology was ready and a 5 to 6 year schedule was reasonable to accomplish the DDT\&E required to retrofit electric actuators into the existing shuttle orbiters. JSC is also supporting an analysis of 10 Shuttie subsystem processing costs and turn-around flows. The EMA system is planned as the vanguard item to trade agafnst the existing hydraulic systems. Shuttle "C" is a cargo version of the Space Shuttle, which will benefit significantly by application of electrical actuation systems.

\section{Civil Transport: Power-by-Wire/Fiy-by-Light}

This program is a planned new initlative for FY91/92. The power-by-wire (PBW) portion of the program includes an all electric secondary electrical power system that includes electrical actuators, embedded englne generators, fixed bleed turbine engines, advanced power distribution architectures. BITE and electric driven environmental control systems. Studies at Lewis on a Boeing 767 class alreraft have shown a potential weight and fuel savings of nearly 10 percent by using the PBW approach. Plans in this initiative include development, fabrication, testing and flight evaluation of engineering prototypes by 1996.

\section{Lunar/Mars Initiative}

Preliminary assessments have been made by the agency for a report to the Space Council. Several scenarios, however, require relatively high power distribution systems and include surface rovers and mining vehicles that will require rellable, power efficient actuation and variable speed motor orive systems.

\section{AF/WROC - More Electric Airolane - Retrofit of F-16}

Wright Research and Development Center under their More Electrlc Airplane Program has contracted General Dynamics of Fort Worth, TX to do a trade study of the F-16 resulting in development costs, risks, and payoffs expected by replacing hydraulics with electrical actuation systems. Performance, operability, maintainability and recurring cost reductions are the main drivers.

\section{David Taylor Ship R\&D Center - Electric Navy}

The US Navy has begun a masstve joint program with DARPA to deve?OD technologies that will enable all electric vartable speed drives of both the main propulstion engines and new weapon systems. This will require megawatts of power generation and distribution capability with new types of electronic control and motor drives. They plan to demonstrate a $200 \mathrm{hp}$ drive by the end of 1991 and work toward a capablilty to drive 3600 hp induction motors. Motor drives and the required very high power MCTs and associated electronic components are already under intensive development and planned qualification. New programs include development of electric actuators to replace many hydraulic actuation systems. 


\section{Commercial Technology Transfer}

Several applications are being explored through the NASA Lewls Research Center Technology Utilization office to apply the advanced electrical distribution system and actuation systems within the commercial sector. The capability to drive induction motors at variable speed with independent control of torque, speed and direction opens up a vast opportunity. Nearly 70 percent of all electrical power consumed in the US drives induction motors. The capability to control these motors more eff $1-$ ciently and in servo applications could revolutionlze many industrial motor applications. In addition many companies are investigating innovative electrical applications to automobiles, other vehicles, appliances and many other products.

\section{Summary}

Electrical actuation, advanced electrical power and avionics systems are ready today for flight validations. Figure 4 is a summary of the
General Dynamics Space Systems assessment of technology readiness of electric actuation for ALS and the National Space Transportation System (NSTS). System requirements, specific DOT\&E and resources. however, are needed to bring the technology to maturity in a particular system application.

Adoption of Total Quallty Management (TOM) practices on other systems besides ALS could cause a revolution in achleving reduced operations costs and improved operabllity of systems such as the NSTS. To incorporate TQM, however, will require some significant cultural changes that bring several NASA organizational codes to work together in such a manner that candidate technologies from the R\&D sectors can be focussed and brought to maturity in the appropriate environment. In this regard NASA is planning a technology bridging program in which one of the pilot initiatives will be to mature electrical actuators/power systems for advanced space vehicle applications.

TABLE I. - ALS FAMILY OF ELECTRIC ACTUATORS MEET STS NEEDS

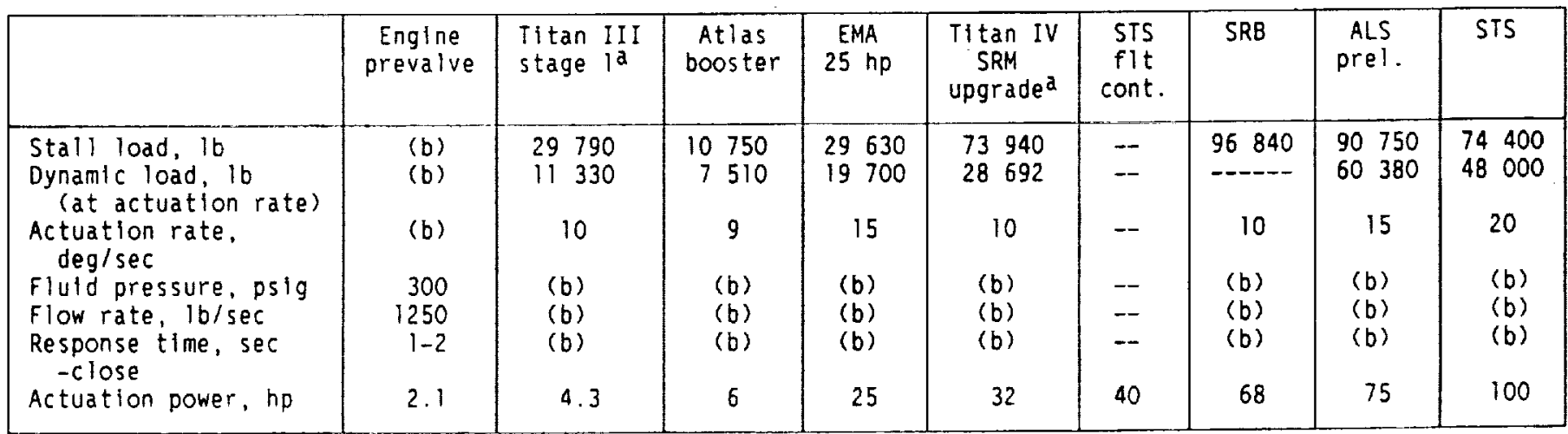

a"Applicable TVC for ALS and MOOG POsition Statement," MOOG Inc., Missle System Division, East Aurora, New York 14052

bparameter not applicable. 


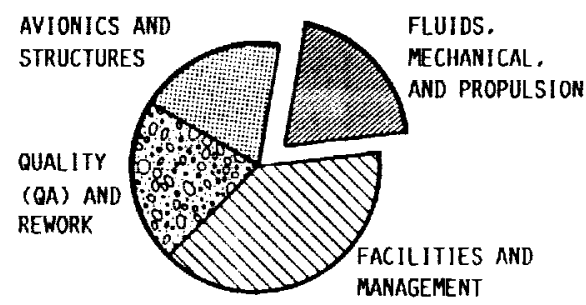

TOTAL AC LAUNCH OPERATIONS 91575 HRS

\begin{tabular}{|c|c|c|c|}
\hline TOTAL IF MMP TEST TIME & $19197 \mathrm{HRS}$ & $\begin{array}{l}x \text { SAVINGS } \\
\text { JF EMAS USED }\end{array}$ & SAVINGS \\
\hline FLUIDS & 4929 HR & $10 z$ & 490 \\
\hline HYDRAULICS & $217 \overline{7 R}$ & $90 \%$ & 1960 \\
\hline PNEURATICS & $5143 \mathrm{HR}$ & $40 x$ & 2060 \\
\hline PROPULSION & $4616 \mathrm{HR}$ & $20 \pi$ & 920 \\
\hline RCS & $2333 \mathrm{HR}$ & $>8 \%$ & 0 \\
\hline
\end{tabular}

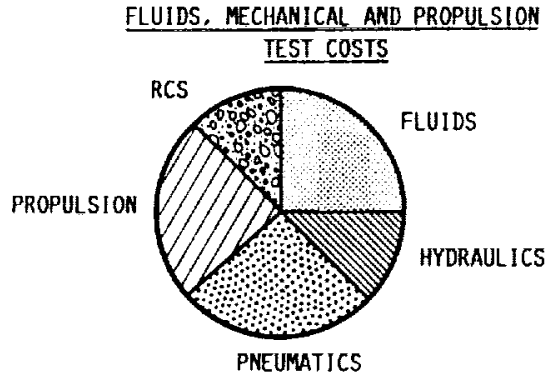

TOTAL STS LAUHCH OPS 326444 HR EOUIVALENT SHUTTLE HOURS

\begin{tabular}{lrrr}
$\begin{array}{l}\text { PLUMBING, VENT. } \\
\text { AND DRAIN }\end{array}$ & $2880 \mathrm{HR}$ & $20 \%$ & 576 \\
HYDRAULICS & $4236 \mathrm{HR}$ & $90 \%$ & 3812 \\
PROPULSION & $27200 \mathrm{HR}$ & $10 \%$ & 2720 \\
ACS & $5654 \mathrm{HR}$ & $>8 \%$ & 0 \\
\hline
\end{tabular}

VAB ACTIVIIIES PAD OPERATIONS (35\%)

\begin{tabular}{l}
5670 \\
3600 \\
\hline 16378 HR \\
\hline
\end{tabular}

USE OF ELECTROMECHANICAL VALVES AND ACTUATORS CAN REDUCE AVC TEST TIME BY >5000 HR, AND POTENTIALLY >16 000 HR FOR THE SHUTTLE

FIGURE 1. - POTENTIAL SAVINGS FROM ELECTRIC ACTUATORS.

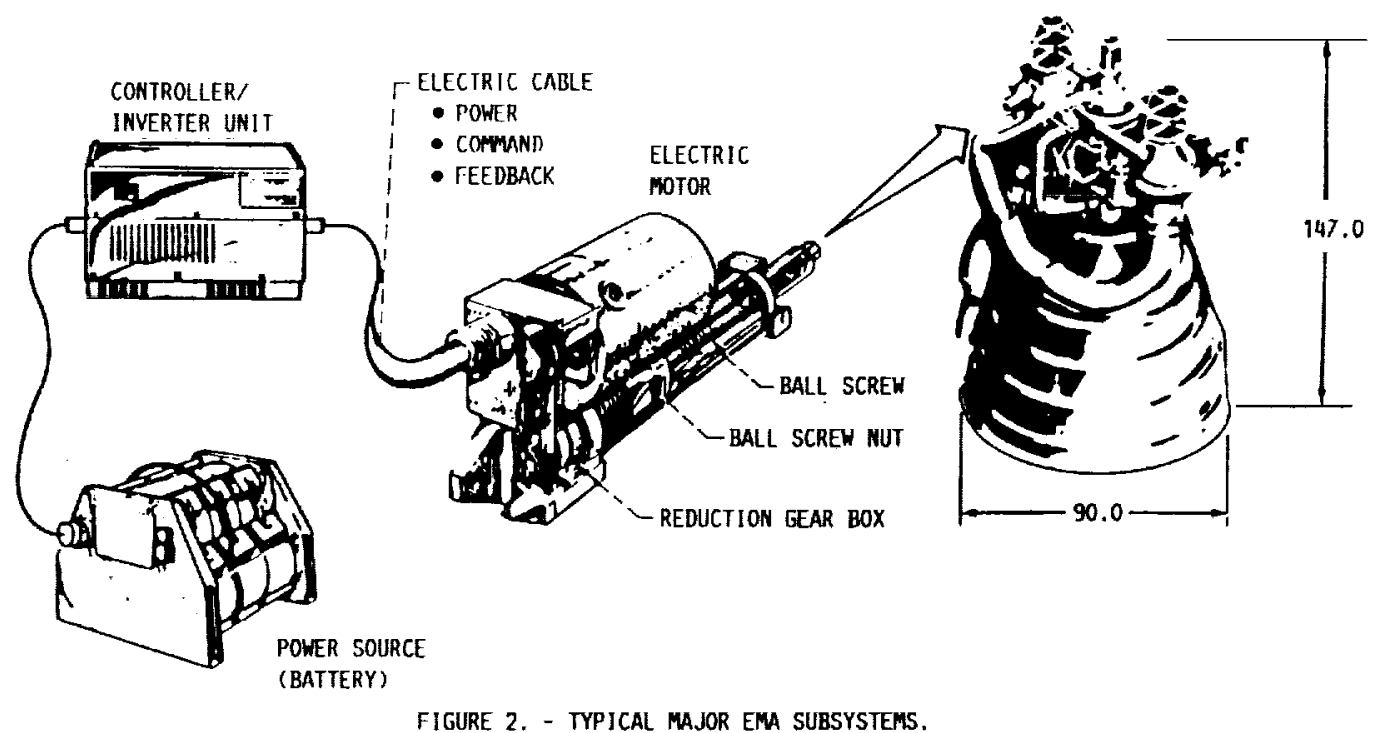




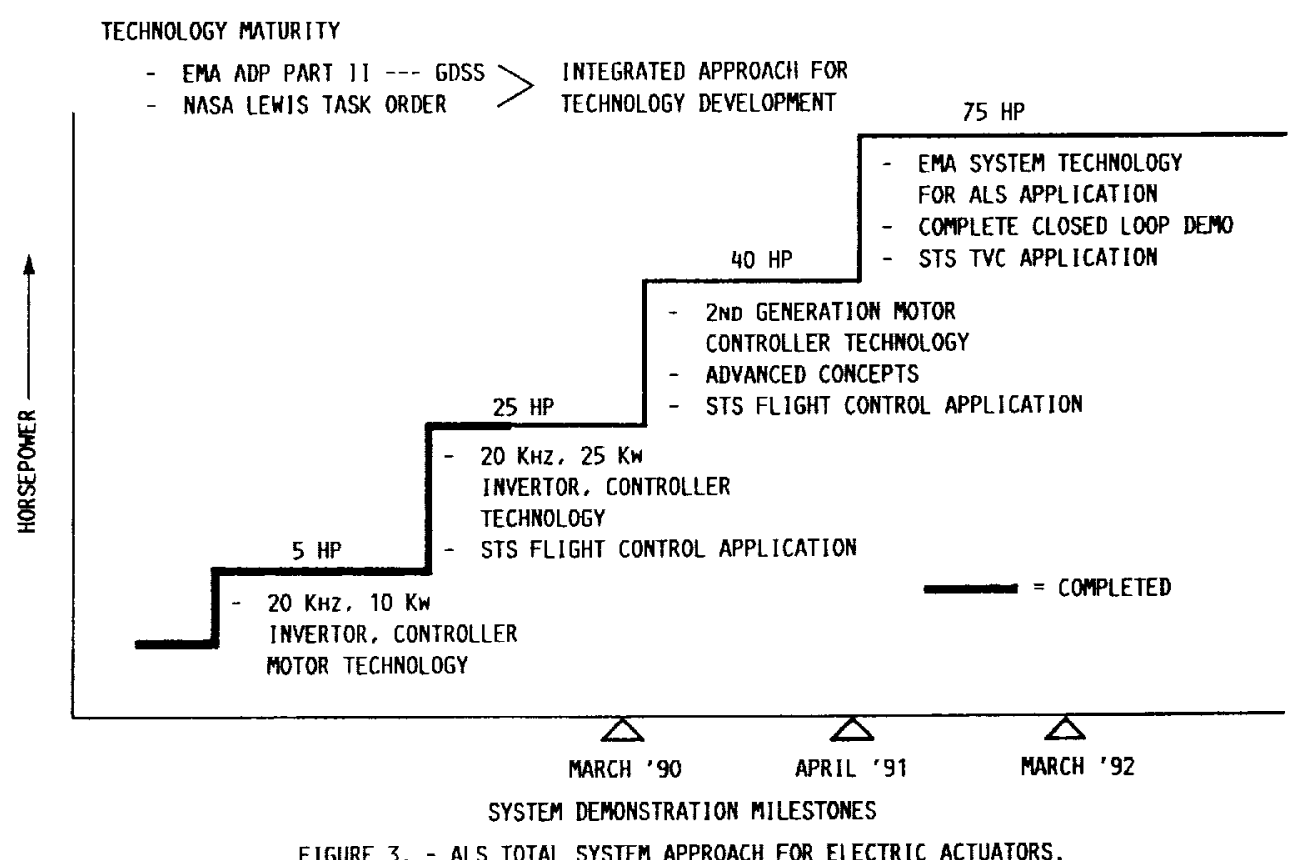

SUMMARY

- prel iminary ema trades are complete

- als REFERENCE VEHICLE

- shuttle orbiter class vehicles

- hardware designs are nOW in work

- ORDERLY PROGRESSION TO FULL POWER

- all the basic reguired technologies are available

- power processing technOlOgy and COMPONENTS

- ac motors

- computer controls and motor control algorithmS

- mechanical components

FIGURE 4. - GEMERAL DYHAMICS ASSESSMENT OF TECHNOLOGY READINESS FOR ELECTRIC ACTUATORS. 


\begin{tabular}{|c|c|c|c|c|c|}
\hline \multicolumn{6}{|c|}{ Report Documentation Page } \\
\hline & $\begin{array}{l}\text { Report No. } \\
\text { NASA TM-102547 }\end{array}$ & \multicolumn{2}{|c|}{ 2. Government Accession No. } & \multicolumn{2}{|c|}{ 3. Recipient's Catalog No. } \\
\hline \multicolumn{2}{|r|}{ 4. Title and Subtitle } & & & \multicolumn{2}{|l|}{ 5. Report Date } \\
\hline \multicolumn{4}{|c|}{$\begin{array}{l}\text { Advanced Launch System (ALS): Electrical Actuation and } \\
\text { Power Systems Improve Operability and Cost Picture }\end{array}$} & 6. Performing $\mathrm{O}$ & zation Code \\
\hline & \multicolumn{3}{|l|}{ Author(s) } & \multicolumn{2}{|c|}{$\begin{array}{l}\text { 8. Performing Organization Report No. } \\
\text { E-5358 }\end{array}$} \\
\hline \multicolumn{4}{|c|}{$\begin{array}{l}\text { 9. Performing Organization Name and Address } \\
\text { National Aeronautics and Space Administration } \\
\text { Lewis Research Center } \\
\text { Cleveland, Ohio } 44135-3191\end{array}$} & \multirow{2}{*}{\multicolumn{2}{|c|}{$\begin{array}{l}\text { 13. Type of Report and Period Covered } \\
\text { Technical Memorandum }\end{array}$}} \\
\hline & \multicolumn{3}{|c|}{ Sponsoring Agency Name and Address } & & \\
\hline & \multicolumn{3}{|c|}{$\begin{array}{l}\text { National Aeronautics and Space Administration } \\
\text { Washington, D.C. 20546-0001 }\end{array}$} & \multicolumn{2}{|c|}{ 14. Sponsoring Agency Code } \\
\hline \multicolumn{6}{|c|}{ 15. Supplementary Notes } \\
\hline & \multicolumn{5}{|c|}{$\begin{array}{l}\text { Prepared for the National Aerospace and Electronics Conference (NAECON) sponsored by the Institute of } \\
\text { Electrical and Electronics Engineers, Dayton, Ohio, May 21-25, } 1990 .\end{array}$} \\
\hline \multicolumn{6}{|c|}{$\begin{array}{l}\text { 6. Abstract } \\
\text { To obtain the Advanced Launch Syste } \\
\text { improved operability, there must be si } \\
\text { relative to current vehicle designs and } \\
\text { using electrical actuation integrated wi } \\
\text { and avionics requirements. This paper } \\
\text { Development Program to demonstrate } \\
\text { and cost goals. The electric power and } \\
\text { only to meet the stringent ALS goals } \\
\text { to } 75 \text { hp), but also those of other laun } \\
\text { multitude of commercial applications. }\end{array}$} \\
\hline \multicolumn{3}{|c|}{$\begin{array}{l}\text { Key Words (Suggested by Author(s)) } \\
\text { Electrical actuators; Electrical power systems; } \\
\text { Electromechanical; Electrohydraulic; Conditioning; } \\
\text { Control; Distribution; Launch vehicles; Space } \\
\text { transportation }\end{array}$} & \multicolumn{3}{|c|}{$\begin{array}{l}\text { 18. Distribution Statement } \\
\text { Unclassified-Unlimited } \\
\text { Subject Category } 33\end{array}$} \\
\hline & $\begin{array}{c}\text { Security Classif. (of this report) } \\
\text { Unclassified }\end{array}$ & 20. Security $\mathrm{C}$ & $\begin{array}{l}\text { of this page) } \\
\text { assified }\end{array}$ & $\begin{array}{c}\text { 21. No. of pages } \\
6\end{array}$ & $\begin{array}{l}\text { 22. Price* } \\
\mathrm{AO} 2\end{array}$ \\
\hline
\end{tabular}

